\title{
Merkel Cell Carcinoma Pathologic Distant Metastasis TNM Finding v7
}

National Cancer Institute

\section{Source}

National Cancer Institute. Merkel Cell Carcinoma Pathologic Distant Metastasis TNM

Finding V7. NCI Thesaurus. Code C88532.

A pathologic finding about one or more characteristics of Merkel cell carcinoma,

following the rules of the TNM AJCC V7 classification system as they pertain to distant metastases. (from AJCC 7th Ed.) 